\title{
Leveraging Technology for Educational Inclusion
}

\author{
Sudha Subramaniam ${ }^{1, *}$, Radha Subramaniam ${ }^{2}$ \\ ${ }^{1}$ M.L.Dahanukar College of Commerce, University of Mumbai, India \\ ${ }^{2}$ State University of New York, BUFFALO, USA
}

Copyright $\bigcirc 2017$ by authors, all rights reserved. Authors agree that this article remains permanently open access under the terms of the Creative Commons Attribution License 4.0 International License

\begin{abstract}
The divides created by inequalities of income, lopsided growth and by the vicious circle of poverty has ensnared learning and delayed the planned strategies for educational inclusion. India's eighth Five-Year Plan prioritised and allocated increased funding for education with focus on reach-out to the remote interiors and rural India. However, those who were outside the circle of inclusion decreased only marginally and the deviations from targets were a matter of genuine concern. Lack of mid-course corrective measures compounded with spiraling economic concerns widened the gulf between the haves and the have-nots. Skill development to enable taking up of opportunities and leveraging with technology to simplify reach-out with innovative methods will serve to unleash the untapped potential and thereby elevate lifestyles by ably empowering. 'Young India' with a population of 234 million in the age group of 15-24 years is expected to increase by $13 \%$ over $2005-2020$ vs the world average of $4 \%$. Channelising the youth by providing them access to global domains of knowledge and leveraging technology ably so as to usher in innovative strategies which are cost-effective can provide the desired reach-out for knowledge to be ingrained productively and seamlessly, eliminating barriers of distance, time, access and reach-out.
\end{abstract}

Keywords Planned Strategies, Educational Inclusion, Mid-course Corrective Measures, Skill Development, Untapped Potential, Leveraging with Technology, Global Domains of Knowledge, Eliminating Barriers

\section{Introduction}

With the passage of time, the world is encompassed as one. The frontiers of education are global and the avenues to the endless reservoirs of knowledge must essentially be unfettered and available to those who thirst for the same.

As we make positive inroads, we need to synchronise with the advancements made and this is where lacunas in technology need to be bridged while simultaneously innovating to ensure that the needs of the immediate external environment are aptly addressed and not juxtaposed in a manner subservient to the needs of the higher echelons of society who may constitute a minority.

Especially so, in the Indian diaspora, where widening inequalities of income, lopsided growth and other ills that plague the economy needs to be addressed with the double-edged tool of knowledge combined with technology to innovate with efficiency. Educational Inclusion is a vital necessity for an empowered youth who constitute the Knowledge Brigade can be the game-changers that India needs.

\section{Defining the Problem}

According to the Higher Education Summit 2011, 44\% of Central Government spend on higher education is allocated to the UGC, which, in turn, assists colleges mainly in the form of grants for their maintenance and development. With a GER of $13.8 \%$ and enrolment of 14.6 million, access to higher education in India is currently restricted to a limited population. Majority of institutions offering programmes in professional disciplines such as engineering, pharmacy, and hotel management have been established by the private sector. As of 2006-07, private sector participation ranged from $50 \%$ to $95 \%$ of the total number of institutions for professional courses. India has the largest target market in the world, with a population of 234 million in the age group of 15-24 years. India's youth population of 18-24 years is expected to increase by $13 \%$ over $2005-2020$ vs the world average of $4 \%$. We need to channelize our youth by providing them access to global domains of knowledge and we need to ensure educational inclusion. This can be done only by leveraging technology ably so as to usher in innovative strategies which are cost-effective, can provide the desired reach-out and can be utilized productively and seamlessly, eliminating barriers of distance, time, access and reach-out.

Hypothesis: Digitisation of Education leveraged with technology and innovation can ensure cost-effective educational inclusion while simultaneously ensuring access to greater domains of knowledge. 
Ho1: There is no strong relation between the use of technology and innovation to ensure educational inclusion.

Ho2: There is no relation between educational inclusion and ensuring greater access to domains of knowledge, leveraged by technology.

\section{Research Methodology}

The Research Methodology followed is exploratory as well as scientific, based on an analysis of factual data from reliable sources, gathering secondary data from Reference Books, Reliable sources like Governmental Publications and News Articles, as well as reliable primary data already gathered by reliable Survey groups were analysed to yield results to frame our findings and draw our conclusions. In addition to primary data gathered from think tanks and survey groups, the primary data was gathered through a well-structured questionnaire which captured responses on a Likert 5-point scale. This data was further statistically analysed and interpreted with statistical tools and techniques.

\section{Objectives}

1) To analyse the extent of educational inclusion achieved.

2) To analyse the available means to leverage technology in an innovative manner to achieve major inroads in education and to study the same with respect to specific examples.

3) To gather relevant data regarding digitisation of education in India and the futuristic perspective of the same.

\section{Findings}

The responses are received on Likert 5 point scale analysis to the question 2 as follows:

Q. Leveraging technology to ensure greater access to domains of knowledge will ensure educational inclusion.
1. Strongly Disagree
2. Disagree
3. Neutral
4. Agree 5. Strongly Agree

The frequency distribution of responses is:

Question2

\begin{tabular}{cc} 
Mean & 3.323529412 \\
Standard Error & 0.126479265 \\
Median & 4 \\
Mode & 4 \\
Standard Deviation & 1.042974742 \\
Sample Variance & 1.087796313 \\
Kurtosis & -0.870142872 \\
Skewness & -0.36652191 \\
Range & 4 \\
Minimum & 1 \\
Maximum & 5 \\
Sum & 226 \\
Count & 68 \\
\hline
\end{tabular}

To test Ho, we have test Z: 2.5579640426 (mean Hypothetical mean) / Std. Error i.e.

$$
(3.323529412-3) / 0.126479265=2.5579640426
$$

Using one tailed test, and LOS $=5 \%$, Critical region, Since calculated $\mathrm{Z}$ is greater than tabulated $\mathrm{Z}$, We reject Null Hypothesis at $5 \%$ LOS.

Thus accept H1: Leveraging technology to ensure greater access to domains of knowledge will ensure educational inclusion.

With an estimated 1,027 million people, India is the world's second most populated country. It has 17 percent of the global population and 20 percent of the world's out-of-school children. Despite impressive gains in the last few decades (11th largest industrial power, 4th largest economy in terms of purchasing power parity) India still has more than 260 million people living in poverty (Canadian International Development Agency [CIDA]. 2003). A large number of children with disabilities live in families with income significantly below the poverty level. While disability causes poverty, it is also possible that in a country like India, poverty causes disability. The combination of poverty and disability results in a condition of "simultaneous deprivation." According to Harriss-White (1996), this is a syndrome that sets up barriers to the participation of persons with disabilities in the normal routines and activities of the community, including regular schooling. Recently, the Ministry of Rural Development, Government of India, has allocated 3 percent funds in poverty alleviation programs targeting families of children with disabilities. However, motivating poor families, with all the associated costs to send their child to school, is proving to be a big challenge[1].

In any analysis of globalization, perhaps the most critical aspect is if, and how, it affects the flow of knowledge and technology across countries. As countries trade, they integrate their economies and move toward new patterns of Production. Young's model above indicates that this can push developing countries into lower growth-as they specialize in producing goods that experience little or no technical progress. The way developing countries can avoid such a situation is to learn the technologies in higher income economies and "leapfrog" up the Product space[2]. A Product innovation is the act of bringing something new to the marketplace that improves the range and quality of Products on offer; e.g., the Apple I Pod is an innovation compared with the Sony Walkman, which was an earlier portable device for plain music. A Process Innovation is a new way of making or delivering goods or services; e.g., going to visit the Doctor and recording that you have arrived for your appointment by touching a screen instead of talking to a receptionist [3]. So also, the life and usefulness of teaching resources is extended by digitizing them, but expert IT advice and a long-term strategy are needed before you begin. Technology may be moving fast, but before digitising your resources you still need to take time to consider practical matters. 
"People often launch into digitisation without thinking about what they are doing," says Karla Youngs, director of the Technical Advisory Service for Images, a service helping people in further and higher education to create and deliver digital images. "They get excited about having a new digital camera or scanner and don't think about the style, format or how they are going to store and describe the resources."[4]. She suggests using a file management system. Training in issues such as imaging theory will help make sure you are getting the most out of your computer and that you are preserving resources responsibly. It should also help ensure that the equipment you have is the right kind for the job.

Alastair Dunning, communications manager at the Arts and Humanities Data Service, notes that how you describe and organise your digitised resources is more complicated than the technicalities of getting them online. A common pitfall, according to Youngs, is to create digital resources for use in teaching without finding out whether the technology needed to use them will be available in the classroom. She opines that even if the digitised texts and images are not used for teaching, Institutional support will be required. This is because the digital files that are created will quickly grow so much that we may be unable to manage them effectively. Library and information services can offer help in organising and preserving materials.

The library should also help with issues of copyright. Dunning says that even if copyright owners waive their rights because the material is going to be used for educational purposes rather than financial gain, we will still need to clear these aspects with them. His experience is that it takes time and effort to get a signed agreement [5].

There are many compelling reasons why the digitisation of education should be embraced.

Around the world, according to UNESCO, an estimated 61 million children of primary school going age are not in school. This is in addition to a further 71 million of lower secondary-school age and almost 800 million adults. The majority of these are in Asia and sub-Saharan Africa [6].

Digitisation of education can assist in addressing many of the factors, including, access to education, affordability, language, distance, and discrimination. Furthermore, it enables the mass delivery of quality education across geographical boundaries. Also, e-learning is easily accessible via the most popular mode of electronic communication on the continent - the cellphone. Africa has the highest mobile Internet connectivity levels in the world, and for many on the continent, a cell phone is the first and probably only 'computer' they will ever own. This makes the inclusion of this tool as a key medium for the delivery of education a logical choice.

Africa is also on the brink of a new and exciting digital era brought about by a combination of African governments' concerted efforts to make ICT a major part of their development plans and the continent's investment in the undersea fibre optic cables. The government of Ethiopia, for example, has invested in billions in the construction of a mega ICT Park, which will potentially be the equivalent of
Silicon Valley in the United States in a few years. The country has prioritised investment in ICT as part of its five-year Growth and Transformational Plan[7].

The main challenge facing the school publisher is with regard to e-learning. We need to develop suitable digital content that can support teaching and learning in the classroom; opined Manzar Khan, Managing Director, Oxford University Press, India.

"What sells for $\$ 55$ (about Rs 2,700) in the United States; retails for Rs 595 in India," said Manzar Khan, Managing Director, Oxford University Press (OUP) India. Mr Khan has been associated with OUP since 1979. He talks to Business Line on the business of education books, the potential of Indian markets and the challenges facing the school text-books business. He says, "The market for English medium books is about Rs 6,000-7,000 crore. This includes fiction, non-fiction, school textbooks etc. Of this, the private school textbook market accounts for Rs 1,000 crore. However, this is only 15 per cent of the total school textbook market. The rest is serviced by the Government. OUP India is Rs 300 crore annual business, of which school textbooks account for over Rs 200 crore. We have 20-22 per cent market share in the private English medium market. India accounts for 5-6 per cent of OUP's turnover. The pie is set to become bigger because India, along with China, is the fastest growing market for us. This market is growing very fast, by 15-20 per cent. The real growth is happening in school textbooks - from primary up to the middle school segment. After Class X, there are quite a few drop-outs. The gross enrolment post-secondary level is only 12 per cent, but the Government is making efforts to raise this to 20 per cent. With India's economic growth fuelling the last decade, the country's education needs have gone up tremendously".

While the country has distinct advantages in terms of enjoying a "demographic dividend" and a heightened government focus on skill development, most of the industries in the economy are currently experiencing a dearth of skilled labor, resulting in the need for an effective skill delivery framework. The current education system in India primarily targets on making skill-based training available to a larger pool of people. As a result, the focus has primarily been supply-driven and not market-driven.

Digitisation is the way forward for supporting teaching and learning. Content has to be developed, digitised and made available. We are, at present, creating a support structure for learning and teaching methods, which are currently available for free. As the demand grows, our digital offering can be monetised. We have a scholarly textbook search engine by the name 'Oxford scholarship online', which we provide to universities on subscription"[8].

Technology is becoming an enabler, It is not only helping marginal farmers increase revenues, but also revolutionizing education, health care and financial inclusion. The other side of the landscape also reveals a dismal picture. In India, even after completing four years of school, $90 \%$ of children from poorer households remain illiterate. And this also holds true for around $30 \%$ of kids from poorer homes despite five to six 
years of schooling. Besides, only $44 \%$ of rural students in the Std V age group in Maharashtra and 53\% in Tamil Nadu could perform two-digit subtraction. And it will take another 66 years for poor young women of the country to achieve universal literacy. These are among the many alarming findings in UNESCO's 11th Education for All (EFA) Global Monitoring Report, which says that despite progress, most EFA goals are likely to be missed by 2015 . According to the report, the pace in achieving universal primary education, lower secondary education and youth literacy is woefully slow for many countries in the region, especially for the disadvantaged. With respect to India, it said while the richest young women have already achieved universal literacy, the poorest are projected to do so only by 2080 .

The business of education is all set for a transformation in the country as the government, recently, announced that it will purchase some 100,000 low-cost Aakash tablets from Datawind, the Canadian company that has developed this equipment. These tablets would then be distributed to schools and colleges in India, where students would get them for free. This move of going the e-way and the limitations the low cost tablet has revealed has seen a lot of criticism all over, however, the e-learning industry in India is going to be one of the biggest game changers in recent times.

E-learning service provider Tata Interactive Systems (TIS) CEO Sanjaya Sharma recalls his experiences when he began his company in 1990.

"There was no e-learning then. It was computer-based training along with multimedia training that existed," said Sharma. However, times changed slowly as TIS began getting clients. One of its first clients was the Confederation of Indian Industry (CII) with whom it did a project involving VGA monitors. This product was later sold to 32 other organisations. Now, the company has many Fortune-500 customers to itself and is also conducting business with universities and publishers abroad. Sharma is very optimistic about the present Indian e-learning market, though he believes that it has just begun to take shape. "Adoption happened much earlier abroad, than in India," Sharma added. TIS is coming big on the e-learning in schools with their Tata Class Edge, a solution for interactive teaching in schools[9].

In Pune, The state forest department's repository of 10,000 books, stored in the Central Forest Libraryin the city, is being digitised to make the resources accessible to officials in the field via the internet. "We are in the process of digitising the entire library. About $80 \%$ of the digitisation process has been completed," said Anurag Chaudhary, chief conservator of forests (research and silviculture). Once all the digitised books have been sorted, they will be uploaded on the department's website www.mahaforest.nic.in, Chaudhary said, adding that the entire library should be functional in the next two to three months. The website URL was launched in June." Some books and publications will also be accessible to the public. All books that are not protected by copyright will be freely accessible. However, access to books protected by copyright will be restricted to officials," he said. The department also has its own publications and reports. These will also be uploaded on the website and access to them will be available to all, he added. The entire exercise will involve scanning of about 10 lakh pages at a cost of 99 paise per page[10].

Inter-University Centre on Electronic Media director, Tilak Kem informed in Pune that work on digitisation of syllabus, right from the school to higher education levels, is in progress and would be duly completed. The energy and resource institute (TERI) and the city-based Raja Rammohun Roy Library Foundation (RRLF) will urge the government to digitise public libraries across the country, said Dr Shantanu Ganguly, fellow at TERI's knowledge management division at an international conference on digital library management organised by TERI in Kolkata. RRLF, under ministry of culture, is the nodal agency for the development of public libraries in the country. The UT art and museum gallery artifacts are also to be digitised soon and finalization of the digitization process has already been initiated.

Technology is the other facet of Knowledge Management and is an important enabler. Technology has provided new impetus to what was an existing practice, but with increasingly structured and efficient ways of knowledge creation, aggregation and dissemination[11].

Information and Communication Technology play a major role in Knowledge Management Processes and the inter-relationship between them. The two primary underpinning roles that ICT's can play in the management of knowledge, from which five other roles are linked, are firstly, in the codification of knowledge, and secondly in the storage of knowledge in some repository. Intermediate to them are the processes of categorization and differentiation, where distinctions are made between the discrete pieces of codified knowledge that exist, based on some system of categorization. Once the codified knowledge that exists has been through these processes, ICT systems can then play a key role in utilizing these frameworks for the storage of knowledge. Thus, for example, structured electronic databases represent one example of an ICT-based knowledge repository [12].

India is expected to grow at a rate of $8 \%$, on an average, in the next 10 years.. More than 700 million Indians are estimated to be of working age by 2022 . Out of these, more than 500 million require some kind of vocational or skill development training.[13]

The Knowledge Sharing Process that can be enabled by technology requires resource as well as operational level planning in a strategic way so as to enhance the knowledge enrichment through the various stages. Digitisation is one of the techniques and works in tandem with the entire flow of sequences and the forethought and planning that must necessarily go into the structuring of the process.

\section{Conclusions}

Greater Educational Inclusion can be achieved by ensuring that education is carried to the remotest areas. 
Provision of engaging animations and videos can help to internalize concepts. Smart classrooms, provision of teaching and lesson planning tools to teachers and required teacher training will enable real-time assessment of learning outcomes, diagnosis, and remediation and ensure that India stays abreast and moves ahead with a strong and continuously updated Knowledge Quotient. India is definitely poised to effectively strategise and leverage technology to ensure that knowledge-ware is accessible to all through proper training and to effectively utilize technology to enrich the learning experience and the dissemination of knowledge. Simultaneously, the need for ensuring holistic education which is the hallmark of a well-groomed and capable youth who can pave the way for a sustainable future is being accorded due importance. Technology has enabled cost-effectiveness with respect to reach-out and inclusion as well as ensured that diverse needs are ably addressed.

Limitations of the Study: The pace at which the world has been rapidly advancing with technological prowess and the immense change that has ushered in the need to learn to do things differently also creates a time lag in the implementation and advancement of different countries and regions at a different rate based on the standard of living, access to technology, training in the use of technology, economic soundness, remoteness of the area and other factors.

Future Scope of the Research: A specific study of a particular geographical area with respect to the extent of educational inclusion achieved and the extent of technological empowerment, availability and access with respect to utilization of knowledge-ware, related job openings and level of advancement may be studied on a comparative basis.

\section{REFERENCES}

[1] Integrated Education in India: Challenges and Prospects, Dr.Sharma Umesh \& Dr.Deppeler Joan, Clayton University Press, Clayton.

[2] Innovation, Intellectual Property and Economic Growth-Authors Christine Greenhalgh and Mark Rogers, Princeton University Press, Princeton and Oxford, Copyright 2010, p.250.Ibid,p.3.

[3] http://www.timeshighereducation.co.uk/news/digitising-archi ves/400336.article Ibid

[4] Article-'Digitization will change the face of education', Verkade Pieter, Daily Monitor-Uganda, July 1st 2013.Ibid

[5] Article, Digitisation of Education is the Way Forward, Khan Heena, The Hindu Businessline, March 11th 2012.

[6] Article, DHNS-Digitisation is making e-learning simple, Ghosh Shravan, Feb 13th 2012

[7] Article, Forest department library to go online, Dutta Ananya, The Times of India, Pune, Aug 19th 2013

[8] Knowledge Management, Bank Economists Conference, 2003, Vol. VI, Edited by Dr. Nagarajan. N, ICFAI Books, The ICFAI University Press.p.6.

[9] Knowledge Management in Organisations, Hislop Donald, Oxford University Press, 2005, p.107.

[10] Article, Forest department library to go online, Dutta Ananya, The Times of India, Pune, Aug 19th 2013

[11] Knowledge Management, Bank Economists Conference, 2003, VolVI, Edited by Dr. Nagarajan. N, ICFAI Books, The ICFAI University Press.p.6.

[12] Knowledge Management in Organisations, Hislop Donald, Oxford University Press, 2005, p.107.

[13] "Bridging India's skills gap," The Hindu website, http://www.thehindu.com/ 